Requests for reprints should be addressed to A T Willis, Public Health Laboratory, Luton and Dunstable Hospital, Lewsey Road, Luton LU4 ODZ.

\author{
References \\ ${ }^{1}$ Everett, M T, Brogan, T D, and Nettleton, J, British fournal of Surgery, \\ 1969, 56, 679 . \\ ${ }^{2}$ Jackson, D W, Pollock, A V, and Tindal, D S, British fournal of Surgery, \\ $1971,58,340$. \\ 3 Davidson, A I G, Smith, G, and Smylie, H G, British fournal of Surgery, \\ $1971,58,326$. \\ 4 Burton, R C, British fournal of Surgery, 1973, 60, 363.
}

${ }^{5}$ Nichols, R L, et al, Annals of Surgery, 1973, 178, 453.

${ }^{6}$ Stokes, E J, et al, British fournal of Surgery, 1974, 61, 739.

7 Goldring, J, et al, Lancet, 1975, 2, 997.

${ }^{8}$ Griffiths, D A, et al, Lancet, 1976, 2, 325.

${ }^{9}$ Keighley, M R B, et al, British fournal of Surgery, 1976, 63, 538

${ }^{10}$ Roy, A D, fournal of Antimicrobial Chemotherapy, 1975, 2, 233.

${ }^{11}$ Leigh, D A, Simmons, K, and Norman, E, fournal of Clinical Pathology, 1974, 27, 997.

12 Leigh, D A, British fournal of Surgery, 1975, 62, 375.

${ }^{3}$ Willis, A T, et al, British Medical fournal, 1976, 1, 318.

${ }^{14}$ Willis, A T, et al, Lancet, 1974, 2, 1540.

${ }_{15}$ Willis, A T, et al, fournal of Antimicrobial Chemotherapy, 1975, 1, 393.

${ }^{16}$ Phillips, K D, Tearle, P V, and Willis, A T, fournal of Clinical Pathology, $1976,29,428$.

(Accepted 31 December 1977)

\title{
Antiribonucleoprotein antibodies in connective tissue diseases: estimation by counterimmunoelectrophoresis
}

\author{
BARRY BRESNIHAN, CHRISTOPHER BUNN, MICHAEL L SNAITH, GRAHAM R V HUGHES
}

British Medical fournal, 1977, 1, 610-611

\begin{abstract}
Summary
One hundred and seventy-two patients with various connective tissue diseases were investigated for the presence of serum antibodies to extractable nuclear antigen (ENA) and its major components, ribonucleoprotein (RNP) and Sm antigen. The counter-immunoelectrophoresis assay allowed independent detection and measurement of antibodies to the different components. All 13 patients with mixed connective tissue disease (MCTD) had anti-RNP antibody in high titres, $16 \%$ of patients with systemic lupus erythematosus (SLE) had low titres, and none of the patients with scleroderma had anti-RNP antibody. MCTD seems to be more benign than either SLE or scleroderma. The counterimmunoelectrophoresis assay is a simple and sensitive technique for confirming the diagnosis.
\end{abstract}

\section{Introduction}

The classification and diagnosis of the connective tissue diseases have been helped by the identification of immunological markers such as circulating antibodies to $\mathrm{DNA}^{1}$ and extractable nuclear antigen (ENA)." Anti-ENA was found in high titres in a group of patients with "overlap" symptoms, who had features of scleroderma, polymyositis, and systemic lupus erythematosus (SLE). ${ }^{3}$ The condition has been called mixed connective tissue disease (MCTD) and was found to have a good prognosis, with renal disease being distinctly uncommon. With the more

\footnotetext{
Department of Medicine, Royal Postgraduate Medical School, Hammersmith Hospital, London W12 0HS

BARRY BRESNIHAN, MB, MRCP, senior registrar

CHRISTOPHER BUNN, medical technician

GRAHAM R V HUGHES, MD, MRCP, consultant physician

Department of Rheumatology, University College Hospital, London WC1

MICHAEL L SNAITH, MD, MRCP, consultant physician
}

widespread measurement of anti-ENA antibodies, it is becoming clear that MCTD may be not only a distinct condition but also one of the more common connective tissue diseases. ${ }^{4}$

ENA is made up of two major components: ribonucleoprotein (RNP), which is sensitive to enzymatic digestion by ribonuclease and a non-nucleic acid glycoprotein, known as $\mathrm{Sm}$ antigen, which is not sensitive to ribonuclease digestion. Most studies of anti-ENA antibodies have used either a passive diffusion assay $^{j-7}$ or a haemagglutination technique, ${ }^{12} 89$ but the former lacks sensitivity and the latter gives confusing results when antibody to RNP and Sm antigen are both present in the same serum. Recently Kurata and Tan used counterimmunoelectrophoresis (CIE), which clearly identifies antibodies to the individual components of ENA. ${ }^{10}$ We therefore used CIE to investigate a large series of patients with various connective tissue disorders.

\section{Patients and methods}

Sera were obtained from 172 patients seen at Hammersmith Hospital (table I). The clinical features of the patients diagnosed as having MCTD are shown in table II. All patients with SLE fulfilled at least four of the criteria of the American Rheumatism Association and had antibodies to double-stranded DNA, detected by the Farr technique. All patients with scleroderma had longstanding disease.

Counterimmunoelectrophoresis-ENA (Pel-Freeze Biologicals Inc, Rogers, Arkansas) was the gift of Dr Eng Tan, La Jolla, California. It was dissolved in $0.9-\mathrm{M} \mathrm{NaCl}$ by stirring overnight at $4^{\circ} \mathrm{C}$. Glass plates were layered with $1^{\circ}$ ", agarose in barbitone buffer, and wells, $3 \mathrm{~mm}$ in diameter, were cut in pairs with the centres $6-\mathrm{mm}$ apart. The anodal well was filled with $8: 2$ l of undiluted serum, and a current of

TABLE I-Prevalence of anti-ENA antibodies in patients with connective tissue diseases

\begin{tabular}{l|c|c|c}
\hline & $\begin{array}{c}\text { No of } \\
\text { patients }\end{array}$ & $\begin{array}{c}\text { No with } \\
\text { anti-ENA } \\
\text { antibody }\end{array}$ & $\begin{array}{c}\text { No with } \\
\text { anti-RNP } \\
\text { antibody }\end{array}$ \\
\hline Normal subjects & 35 & 0 & 0 \\
Patients with: & 13 & 13 & 13 \\
$\quad$ Mixed connective tissue diseases & 90 & 24 & 17 \\
Systemic lupus erythematosus & 13 & 0 & 0 \\
Polymyositis & 32 & 0 & 0 \\
Scleroderma & 24 & 0 & 0 \\
Rheumatoid arthritis & & 0 & \\
\hline
\end{tabular}


TABLE II-Clinical features of 13 patients with MCTD

\begin{tabular}{|c|c|c|c|}
\hline & $\begin{array}{c}\text { No of } \\
\text { patients }\end{array}$ & & $\begin{array}{c}\text { No of } \\
\text { patients }\end{array}$ \\
\hline $\begin{array}{l}\text { Ruynaud's phenomenon } \\
\text { Arthritis or arthralgia } \\
\text { Swollen fingers } \\
\text { Lymphadenopathy } \\
\text { Antinuclear antibody } \\
\text { speckled pattern } \\
\text { Hiypergammaglobulinaemia } \\
\text { Pulmonary abnormalities }\end{array}$ & $\begin{array}{l}13 \\
13 \\
13 \\
13 \\
13 \\
12) \\
10 \\
7\end{array}$ & $\begin{array}{l}\text { Serositis } \\
\text { Dysphagia } \\
\text { Myositis } \\
\text { Central nervous system } \\
\text { manifestations } \\
\text { Nephritis } \\
\text { Anti-DNA antibody } \\
\text { Hypocomplementaemia }\end{array}$ & $\begin{array}{l}6 \\
6 \\
3 \\
1 \\
1 \\
0 \\
0\end{array}$ \\
\hline
\end{tabular}

$3 \mathrm{~mA} / \mathrm{cm}$ was applied for 45 minutes. Then $8 \mu \mathrm{l}$ of ENA, at a concentration of $5 \mathrm{mg} / \mathrm{ml}$, was introduced to the cathodal well and the current applied for a further 30 minutes. The presence of antibody in the serum to individual components of ENA resulted in the appearance of distinct precipitin lines. Positive sera were then made to react with ribonuclease-treated ENA (enzyme to substrate ratio $1: 10$ ). The amount of antibody was measured by serial dilution of positive sera.

\section{Results}

Sera from all 13 patients with the clinical features of MCTD and from 24 of the 90 patients with SLE contained antibody to ENA (table I). A single precipitin line was observed with 17 SLE sera and two precipitin lines appeared with seven. No patient with scleroderma, polymyositis, or rheumatoid arthritis showed anti-ENA antibodies.

After the ENA had been treated with ribonuclease the precipitin line disappeared in sera from patients with MCTD. This indicated that the antibody was directed against the RNP (table I). Seventeen of the 24 positive SLE sera contained antibody to a single component of ENA. The precipitin line was abolished by ribonuclease treatment of ENA in 10, while in the remaining seven sera the antibody was directed against the Sm component. Seven SLE sera showed two precipitin lines and ribonuclease treatment resulted in the loss of one in line in each case (see figure). Thus, serum from 17 out of 90 patients $\left(19^{\prime \prime}{ }^{\prime}\right)$ with SLE contained anti-RNP antibodies, while 14 sera contained anti-Sm antibodies.

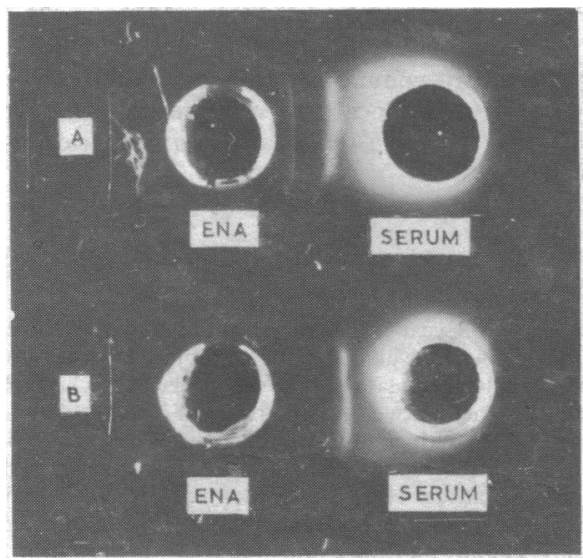

(A) Serum from patient with SLE showed antibodies to two components of ENA. (B) When ENA was treated with ribonuclease the anti-RNP precipitin line disappeared.

The 13 sera from patients with MCTD and the 17 from patients with SLE that contained anti-RNP antibodies were titrated (table III). There was a clear distinction between the two groups. In all 13 MCTD sera anti-RNP antibody was present at serum dilutions of $1 / 64$ or greater, and in one patient anti-RNP antibodies were detectable
TABLE III-Titres of anti-RNP antibodies in patients with MCTD and SLE

\begin{tabular}{|c|c|c|c|c|c|c|c|c|c|c|c|}
\hline Titre: & $1 / 2$ & $1 / 4$ & $1 / 8$ & $1 / 16$ & $1 / 32$ & $1 / 64$ & $1 / 28$ & $1 / 256$ & $1 / 512$ & $1 / 1024$ & $1 / 10000$ \\
\hline $\begin{array}{l}\text { MCTD } \\
\text { SLE }\end{array}$ & & 4 & 3 & 5 & 3 & $\begin{array}{l}2 \\
2\end{array}$ & 2 & 3 & 4 & 1 & 1 \\
\hline
\end{tabular}

at a dilution of $1 / 10000$. In contrast, none of the SLE sera showed anti-RNP antibody at dilutions greater than $1 / 64$.

\section{Discussion}

The combination of Raynaud's phenomenon and swollen fingers, arthritis or arthralgia, and lymphadenopathy suggested a clinical diagnosis of MCTD in 13 patients included in this study. These clinical features are not exclusive to MCTD, but their association with a high titre of anti-RNP antibody characterises a distinct syndrome, which may resemble SLE but in which cerebral and renal manifestations are rare and antiDNA antibodies do not occur. ${ }^{3}{ }^{4}$ Some patients with SLE may have anti-RNP antibodies in their serum, but we observed in this study that the titres were low in all cases, and we could distinguish clearly between SLE and MCTD. MCTD may also have features of scleroderma, but systemic sclerosis of the lung, heart, kidney, or small bowel have not been described in patients with MCTD. Of special interest was the observation that none of our patients with scleroderma had anti-RNP antibody.

The passive diffusion assay of anti-ENA antibody requires several days to perform and lacks sensitivity, while the haemagglutination technique is complicated when both antibody to RNP and antibody to the Sm antigen are present in the same serum, as high titres of anti-Sm antibody may mask lower titres of anti-RNP. The CIE assay we used may be performed rapidly and detects antibody within hours. It also allows independent detection of antibody to RNP and other non-RNP components of ENA, as the presence of each is represented by distinct precipitin lines. Though antibodies to the non-RNP components are largely directed against the Sm antigen, Kurata and Tan have shown that antibody to ENA may occasionally be directed against other antigens, such as the B antigen of Sjögren's syndrome. ${ }^{10}$

While MCTD may resemble either SLE or scleroderma it seems to have a much better prognosis than either of these conditions, and confirmation of the diagnosis is clearly desirable. The advantages of the CIE assay of anti-RNP antibody indicate its suitability for routine use by those investigating patients with connective tissue diseases.

We thank Dr E B D Hamilton, Dr C J Goodwill, and Dr D Golding for referring patients included in this study.

\section{References}

${ }^{1}$ Hughes, G R V, Lancet, 1971, 2, 861 .

2 Sharp, G C, et al, fournal of Clinical Investigation, 1971, 50, 350.

${ }^{3}$ Sharp, G C, et al, American fournal of Medicine, 1972, 52, 148.

${ }^{4}$ Reichlin, M, in Modern Topics in Rheumatology, ed G V R Hughes, p 157. London, Heinemann, 1976.

5 Tan, E M, and Kunkel, H G, fournal of Immunology, 1966, 96, 464.

${ }^{6}$ Reichlin, M, and Mattioli, M, New England fournal of Medicine, 1972, 186, 908.

' Northway, J D, and Tan, E M, Clinical Immunology and Immunopathology, $1972,1,140$.

${ }^{8}$ Notman, D D, Kurata, N, and Tan, E M, Annals of Internal Medicine, $1975,83,464$.

${ }^{9}$ Parker, M D, Fournal of Laboratory and Clinical Medicine, 1973, 82, 769.

${ }^{10}$ Kurata, N, and Tan, E M, Arthritis and Rheumatism, 1976, 19, 574.

(Accepted 6 fanuary 1977) 